2020 TheoLogica

An International Journal for Philosophy of Religion and Philosophical Theology

S. I. CONCILIAR TRINITARIANISM

DOI: https://doi.org/10.14428/thl.v4i2.23593

\title{
Conciliar Trinitarianism, Divine Identity Claims, and Subordination
}

TIMOTHY PAWL

University of St. Thomas

timpawl@stthomas.edu

\begin{abstract}
In this article, I present the trinitarian teaching of the first seven ecumenical councils, what we might call Conciliar Trinitarianism. I then consider two questions. First, what is the relationship between the divine persons and the divine nature? I argue that neither strict identity nor instantiation interpretations of that relationship fit well with the conciliar texts. Second, does the relation of procession among the divine persons, asserted in the conciliar texts, imply an objectionable ontological subordination in the Trinity? I argue that there is at least one way for a proponent of Conciliar Trinitarianism to deny that objectionable ontological subordination follows from the divine processions.
\end{abstract}

Keywords: Conciliar Trinitarianism, Conciliar Christology, Trinity, Subordination, Procession, Identity

\section{Introduction}

The recent shift of focus in Theology, especially Analytic Theology, to theorizing with explicit reference to the teachings of the ecumenical councils is a welcome and important change. The editors of this special edition have done a good work in focusing on the trinitarian theology of the ecumenical councils. In this article, I present the trinitarian teaching of the first seven ecumenical councils, what we might call Conciliar Trinitarianism. Since this marks (I hope) the start of a research program in Analytic Theology, after explicating Conciliar Trinitarianism, I use the remainder of this article to do two things. First, I commend areas in Conciliar Trinitarianism that require more work. Second, I note objections to Conciliar Trinitarianism that need to be met. There is overlap in these two projects. I focus on two questions. First, what is the relationship between the divine persons and the divine nature? Second, does the relation of procession among the divine persons, asserted in the conciliar texts, imply an objectionable ontological subordination in the Trinity? 


\section{What the councils teach about the Trinity}

There are many questions that one might have about the conciliar doctrine of the Trinity. I will focus on the following six questions. What are there three of? What is there one of? What are the relations between the three? What are the relations between the three and the one? What are the attributes of the one? What are the attributes of the three? The councils give answers to all these questions except the fourth, concerning the relations between the three and the one. I go on to discuss potential answers to that question in Section 3.

Concerning the first two questions - what is there one of?; what are there three of? - the councils claim that there is one nature or substance, and that there are three persons or hypostases. To see this, consider a portion of a synodical letter from bishops gathered in Constantinople in the year 382. Sadly, we have no copy of the tome or anathemas from $1^{\text {st }}$ Constantinople, the second ecumenical council. But we do have the above-mentioned letter, which explicates the findings of that council. ${ }^{1}$ The gathered Fathers there write of the Creed of Nicaea that

It tells us how to believe in the name of the Father and of the Son and of the holy Spirit: believing also, of course, that the Father, the Son and the holy Spirit have a single Godhead and power and substance, a dignity deserving the same honour and a co-eternal sovereignty, in three most perfect hypostases, or three perfect persons (Tanner 1990, 28).

We see both questions answered here.

First, we see that there is one "Godhead," "power," and "substance." Shortly thereafter in the text, one finds the same safeguarded negatively, when the bishops condemn the view that there is a "division of substance or of nature or of Godhead" in the persons (Tanner 1990, 28).

Second, we see a distinction between three perfect persons, or hypostases. Again, the same answer is safeguarded negatively shortly thereafter, as the above text continues that the hypostases are not confused, and their proper characteristics are not destroyed. This is meant to fight the views of Sabellius and others, who took the distinctions to be merely mental, not real.

We find the same two answers to these questions taught negatively by way of anathema later at the Second Council of Constantinople, which says, in Anathema 1:

\footnotetext{
${ }^{1}$ For a brief discussion of the history and texts, see Tanner $(1990,21)$.
} 
If anyone will not confess that the Father, Son and holy Spirit have one nature or substance, that they have one power and authority, that there is a consubstantial Trinity, one Deity to be adored in three subsistences or persons: let him be anathema. (Tanner 1990, 114) ${ }^{2}$

In brief, according to the councils, the thing that is one can be referred to as the divine nature, the Godhead, and the divine substance. Elsewhere the Latin translation of Cyril's letters refers to the same one thing as the divine essentia (Tanner 1990, 50, 73). And it is frequently referred to as the divinity (divinitas) as well (Tanner 1990, 40, 80). The things that are three can be referred to as the three divine persons, hypostases, and subsistences. ${ }^{3}$

Consider the next question, concerning the relations between the three divine persons. As later authors will put it, the distinction between the persons is a real distinction, not a distinction of reason. The proper characteristic of the Father is the Father's alone, not the Son's or the Spirit's, not merely in language, but in reality. As Cyril says in his Third Letter to Nestorius, accepted at the Council of Ephesus in 431, "the Spirit exists in his own hypostasis and is thought of on his own, as being Spirit and not as Son, even so he is not alien to the Son" (Tanner 1990, 57). The Spirit really is not the Son. What is the proper characteristic of each person, the characteristic that differentiates them one from another, according to the councils?

Cyril says in the same letter, in the very next sentence, that

the Spirit was poured forth ${ }^{4}$ by the Son, as indeed the Son was poured forth from the God and Father. (Tanner 1990, 57)

Likewise, the Spirit is said to proceed from the Father as well in the exposition of faith from $1^{\text {st }}$ Constantinople (Tanner 1990, 24) and in Cyril's letter to John of Antioch

\footnotetext{
${ }^{2}$ Here as elsewhere in the Tanner translation, the same Greek, hypostasis, is translated into English sometimes as "subsistence" and sometimes merely transliterated as "hypostasis" (see for instance Tanner 1990, 116).

${ }^{3}$ Here and following, I will include footnotes to De fide propositions from Ludwig Ott's The Fundamentals of Catholic Dogma. I do this, not as evidence that the claims are true, but rather as evidence that my interpretation of the councils is not a novelty. Ott's claiming that something is De fide does not show that it is part of Conciliar Trinitarianism, of course, since Ott is Catholic, and so has more sources for De fide propositions than the first seven councils. Ott (1960, 52) writes, "In God there are Three Persons, the Father, the Son and the Holy Ghost. Each of the Three Persons possesses the one (numerical) Divine Essence. (De fide.)."

${ }^{4}$ The Greek here is procheitai; the Latin is procedit.
} 
about peace (again accepted as a text from Ephesus; Tanner 1990, 73). ${ }^{5}$ The divine persons, then, are related to one another such that the Son proceeds from the Father, the Father proceeds from none, and the Spirit proceeds from the Father in a way that, in some manner, includes the Son. ${ }^{6}$ The Son's mode of procession is called begetting in the councils; the Spirit's mode is called spiration at later, western councils that are judged to be ecumenical by the Catholic Church. ${ }^{7}$ Spiration is further subdivided between active and passive spiration, where active spiration is to begetting as passive spiration is to being begotten. We see here an answer to the questions concerning the relations between the persons: the Father is neither begotten nor (passively) spirated; the Son is begotten but not (passively) spirated; the Spirit is not begotten but is (passively) spirated. ${ }^{8}$ They are really distinct from one another, each having proper characteristics that separate one from the others. ${ }^{9}$

Having provided the answers to the first three questions about what is three and what is one, and the interrelations among the three, we do well now to ask about the attributes of the one nature (substance, Godhead, essence, divinity) and the attributes of the three persons (hypostases, subsistences). I will begin with the attributes of the divine nature according to the councils. ${ }^{10}$

The divine nature, according to the councils, is impassible, immutable, unspeakable, and not diminished by the incarnation. ${ }^{11}$ For just a few examples from many that one might cite, the Fathers at Chalcedon write that it is a novel heresy to suppose that "the divine nature of the Only-begotten is passible" (Tanner 1990, 84). ${ }^{12}$ They go on to claim that the council "expels from the assembly of the priests those who dare to say that the divinity of the Only-begotten is passible" (Tanner 1990, 856). Finally, Leo calls the divine nature "invulnerable" (Tanner 1990, 78). Concerning immutability, Cyril writes, in a letter accepted at the council of Ephesus, "those are quite mad who suppose that 'a shadow of change' is conceivable in connexion with

\footnotetext{
${ }^{5}$ Here the Latin is the same, procedentem (1 ${ }^{\text {st }}$ Constantinople) and procedit (Ephesus), but the Greek is erchomenon and ekporeuetai. The procession language is scriptural as well; see John 15:26. I thank Jonathan Rutledge for help with the Greek text.

${ }^{6} \mathrm{I}$ am not here making a case for the Filioque in the early councils.

${ }^{7}$ See, for instance, $2^{\text {nd }}$ Lyons, Constitution II and Florence, Session 6 (July 6 ${ }^{\text {th }}, 1439$ ) (Tanner 1990, 314,526 respectively).

${ }^{8}$ I leave to the side all discussion of who actively spirates so as not to take a stand on the Filioque.

${ }^{9}$ Ott $(1960,61)$ writes, “In God there are two Internal Divine Processions. (De fide)." He goes on to identify those processions as begetting and spirating.

${ }^{10}$ For a more detailed discussion of these attributes and the conciliar texts supporting these ascriptions, see Pawl (2016d, 16-18, 179-90; 2019b, 16-19).

${ }^{11}$ This list is merely representative, not exhaustive.

${ }^{12}$ For other examples, see Tanner (1990, 5, 51, 53, 72-3).
} 
the divine nature of the Word" (Tanner 1990, 72). Cyril's letter to John of Antioch about peace calls the Godhead "unspeakable" (Tanner 1990, 73). Finally, the divine nature loses nothing in the incarnation. As Leo says of the incarnation, "each nature kept its proper character without loss"' (Tanner 1990, 78).

Concerning the final question of the attributes of the persons, we have seen a partial answer to that question in the discussion of the interrelations between the divine persons. Each person has a unique proper characteristic. Moreover, the creeds include many affirmations about some persons that they do not likewise predicate to the others. For instance, only the Son is said to be born of a woman, and it is only the Holy Spirit that is said to speak through the prophets. Likewise, some later anathemas predicate different attributes of the divine persons. For instance, consider this text from an anathema from Second Constantinople:

"There is only one God and Father, from whom all things come, and one Lord, Jesus Christ, through whom all things are, and one holy Spirit, in whom all things are." (Tanner 1990, 114)

What about attributes that are shared among the persons? Concerning shared attributes, they are co-eternal (Tanner 1990, 28, 42, 58, 77, 80), worthy of the same worship (Tanner 1990, 24), of equal glory (Tanner 1990, 24, 79), of equal honor (Tanner 1990, 28), and of equal power (Tanner 1990, 57, 77, 114). ${ }^{13}$ Other nonecumenical but important early councils speak to this issue as well. For instance, the Tome of Damascus from the Council of Rome in 382 says:

Anyone who denies that the Father, the Son, and the Holy Spirit have one Godhead, one might, one majesty, one power, one glory, one Lordship, one kingdom, one will and truth, is a heretic. (Dupuis 2001, para. 306/20)

The same council affirms that the Father, Son, and Spirit each "can do all things, knows all things and is everywhere present" (Dupuis 2001, paras. 306/12, 306/17). It also affirms that all three are "equal, living eternally, containing all things visible and invisible, all-powerful, judging, creating and saving all things" (Dupuis 2001, para. 306/21).

At this point, I've answered five of the six questions with which I started. What is there one of? Nature, substance, divinity, essence, Godhead. What are there three of? Persons, hypostases, subsistences. How are these three persons related to one

${ }^{13}$ This list is merely representative and not intended to be exhaustive. 
another? They are really distinct and related by procession. What are the attributes of the divine nature? It is impassible, immutable, unspeakable, and undiminished by the Son's incarnation. What are the attributes of the persons? They are alike in eternality, worshipfulness, glory, honor, and power. They are unalike in procession and in some assertions from the Creeds and anathemas. In particular, they are unalike in incarnational predicates (e.g., only the Son was born of Mary). But what of the sixth question: the relation between each person and the divine nature? I do not see that question answered in the councils.

In what follows, I will discuss two questions, the first of which concerns the relation between the persons and the nature-we might call this the Person-Nature question. The second takes up an objection to the consistency of the content of Conciliar Trinitarianism.

\section{What is the Relation between the Divine Persons and the Divine Nature?}

As noted above, I am unaware of any text in the first seven ecumenical councils that determines one unique understanding of the relation between each divine person and the divine nature. That said, there are some contenders for that relation which have some initial support yet are inconsistent with Conciliar Trinitarianism. I will focus on two common relations considered in the literature: strict identity and instantiation. Much of this discussion will be familiar to those who know the literature on so-called Latin and Social models of the Trinity. ${ }^{14}$ What novelty there is in this section will be in relating the argumentation to the teachings of Conciliar Trinitarianism and in the second objection to the instantiation view. To reiterate, my goal in each of the two following subsections is to show that two answers to the Person-Nature question, even though they have some initial support, are inconsistent with Conciliar Trinitarianism.

\footnotetext{
${ }^{14}$ A nearby question to the one discussed in this section is the question of what the "is" in "the Father is God," or "the Son is God," or "the Holy Spirit is God" means. There has been much discussion of this topic. For recent examples, see Baber (2002; 2008; 2015; 2016; 2019), Bohn (2011), Cain (2016), Davidson (2016), Fisher (2016), Grant and Spencer (2015), Hasker (2009; 2013; 2016; 2017a; 2017b; 2018; 2019), Jedwab (2015), Jedwab and Keller (forthcoming), Leftow (1999; 2009; 2010; 2012; 2018), Long (2019), McCall (2014), Molto (2017), Mooney (2018), Mullins (2017), Owen and Dunne (2019), Page (2017), Paoletti (2019), Pickup (2016), Spencer (2017), Swinburne (2018), Thom (2012), Tuggy (2013), White (2016a; 2016b), Williams (2013; 2017).
} 


\subsection{Strict Identity}

When philosophers speak of identity, they often mean what I will call strict identity. Strict identity is reflexive (everything is identical to itself), it is symmetric (if $a=b$, then $b=a$ ), and it is transitive (if $a=b$ and $b=c$, then $a=c$ ). Moreover, it obeys Leibniz's Law: if $a=b$, then anything true of $a$ is true of $b$, and vice versa. ${ }^{15}$ The view under consideration here is the view that each divine person is strictly identical with the divine nature. ${ }^{16}$

There is some reason to think that the relationship between the persons and the nature should be understood as strict identity. For one reason, which we will see more fully developed in the discussion of instantiation below, if the relation weren't strict identity, it would be hard to see how monotheism is true. For another reason, as we will see in the paragraphs that follow, we find language in the translations of the councils and in scholarly and historical works on the Trinity that describe the relationship between the persons and the nature using the language of "identity," or "sameness," or an emphatic "is."17 Finally, as Brian Leftow writes (using "absolute" to mean what I mean by "strict") in his presentation of the logical problem of the trinity,

Here and elsewhere, 'identity' expresses absolute identity. This first section only sets up a problem many have considered. If the identity reading of 'is' here and in similar contexts were not at least plausible, no one would have thought there was a problem to think about. (Leftow 2018, 375)

I agree with Leftow - if we didn't begin with at least a presumption of strict identity, then we wouldn't have been worried about there being three distint persons, each of which "is," in some sense, God.

Reflection on what the tradition has said about the relation between the divine nature and the divine persons shows that we ought not to answer the question of the relation between the nature and persons by appeal to strict identity. We can

\footnotetext{
${ }^{15}$ Sometimes the Law is stated in terms of "properties" rather than things true of. That way of stating it builds more ontology into it than is necessary to present the Law. We don't need to quantify over properties - or, at least it is a contested point - in order to understand that if Joseph and Dr. Jedwab are identical, then if it is true that Joseph casts a shadow, then so does Dr. Jedwab. No need to posit the property of casting a shadow here to use Leibniz's Law.

${ }^{16}$ In this section I am assuming a standard semantics of names and analysis of definite descriptions that also involve strict identity. For a different take, see Rea and Brower $(2005,70)$.

${ }^{17}$ For instance, Ludwig Ott $(1960,68)$ writes: "The Relations in God are really identical with the Divine Nature (De fide)."
} 
show both that the traditional understanding of identity in question is not strict identity and show the contradictions inherent in viewing the relation as strict identity by focusing on a later conciliar pronouncement.

The Fourth Lateran Council (1215) is reckoned an ecumenical council by the Catholic Church but is not one of the first seven ecumenical councils, and so its documents do not count as part of Conciliar Trinitarianism, as defined here. That said, it is an important work in the western church prior to the Protestant Reformation. In it, we find one of the most detailed discussions of the Trinity from later councils. This discussion, entitled "on the Error of Abbot Joachim," vindicates the trinitarian teaching of Peter Lombard against the charges of heresy which Joachim leveled against it. At this medieval council, the Church Fathers wrote:

There exists a certain supreme reality [summa res], incomprehensible and ineffable, which truly is the Father and the Son and the holy Spirit, the three persons together and each one of them separately. Therefore in God there is only a Trinity, not a quaternary, since each of the three persons is that reality - that is to say substance, essence or divine nature - which alone is the principle of all things, besides which no other principle can be found... Although therefore the Father is one person, the Son another person and the holy Spirit another person, they are not different realities, but rather that which is the Father is the Son and the holy Spirit, altogether the same. (Tanner 1990, 232)

The content omitted in the ellipsis is an important two sentences to which I will return. But now, notice the sameness language of the passage. The nature truly is each person; each person is that reality; they are not different realities; that which is the Father is the Son, altogether the same. Emphatic affirmations like this lead some people to take the claims to be strict identity claims.

That said, they cannot be strict identity claims. And, in fact, the omitted two sentences show us why. They read:

This reality neither begets nor is begotten nor proceeds; the Father begets, the Son is begotten and the holy Spirit proceeds. Thus there is a distinction of persons but a unity of nature. (Tanner 1990, 232)

If the relation that the Fathers were after in talking about the persons truly being the nature, or being altogether the same as the nature, and so on, were the relation of strict identity, then Leibniz's Law would hold among the things so related. But Leibniz's Law does not hold between them. For that reality, which really is the Father, which is altogether the same as the Father, does not beget. And the Father 
does beget. ${ }^{18}$ The same is true for the proper processional characteristics of the other two divine persons. Thus, strict identity was not the relation the later, Western church had in mind.

Moving back to the texts of Conciliar Trinitarianism, we see that the strict identity of each person with the nature is something inconsistent with Conciliar Trinitarianism. Christ suffered, but the divine nature cannot suffer. Again, the divine persons and the divine nature do not have the same attributes, and so, by Leibniz's Law, they are not identical in the strict sense of identity.

A second problem is commonly raised for theories of the Trinity that employ strict identity as the relation between each divine person and the divine nature. Suppose again, for argument, that the Father is strictly identical to the divine nature, and that the Son is strictly identical to the divine nature. Using symmetry, we can derive from "the Son is strictly identical to the divine nature" that the divine nature is identical to the Son. By transitivity, then, we can derive that, since the Father is identical to the divine nature and the divine nature is identical to the Son, the Father is identical to the Son, identical in the strict sense. But this is contrary to the conciliar teaching, as we've seen. There are three different persons (hypostases) who have their own proper attributes and are not confused.

The traditional way this second objection is put is as follows: Any two things identical with a third are identical with one another. The Father and Son are each identical to a third thing: the divine nature. So, the Father and Son are identical with one another. We might summarize the moral here as follows: if the conciliar Fathers meant that each person is strictly identical to the divine nature, then, on Conciliar Trinitarianism, the Father is strictly identical to the Son. But he isn't. And they didn't think he was. So, this is a bad interpretation of their view.

A third sort of argument combines both the preceding arguments. It begins by showing, through transitivity and symmetry, that one divine person is strictly identical with another. It then applies the predicates apt of one, via Leibniz's Law, to the other. In this manner we can derive, supposing again that the persons are each strictly identical with the divine nature, that the Father is begotten, that the Holy Spirit suffers on the Cross, etc. Such claims, though, are inconsistent with the teaching of the first seven ecumenical councils. Conciliar Trinitiarianism is inconsistent with the "strict identity" answer to the Person-Nature question.

Some might object here that, instead of tinkering with the councils and "real identity," we ought instead to tinker with how we understand strict identity. I agree

${ }^{18}$ Ott $(1960,61)$ writes: "The Divine Persons, not the Divine Nature, are the subject of the Internal Divine processions (in the active and in the passive sense). (De fide.)." 
in a sense: I don't want to tinker with the councils. That said, I'm writing for a contemporary analytic audience, and those folks have a very clear idea of what "strict identity" is, and a nebulous idea at best of what real identity is, if it doesn't mean strict identity. My intent here isn't to change what the councils said; it is to get clear on which views are consistent with what they said. One view that is not consistent with what they said, in my estimation, based on these three preceding arguments, is that the persons are identical with the Divine nature in the strict sense I stipulated above.

Another might object that I have a faulty hermeneutic here. I'm employing something like a principle of charity in a situation where it is unwarranted. Perhaps they were all just severely confused or lacked logical proficiency, and so were incapable of seeing the problem. Or perhaps they could see the problems with such claims but were slavishly tied to traditional language, affirming a contradiction anyway. Or perhaps they saw the problems but affirmed the strict identity claims for savvy political reasons. Or perhaps there was a mixture of motivations, with some being stupid, some slavish, some savvy, and perhaps some unfortunate souls being all three.

I have no doubt that some bishops fit each of those three groups. But I see little reason to think that some bishops fitting into such groups forces upon us an interpretation of the councils such that strict identity is the relation between the nature and the persons of the Trinity.

Concerning slavish acceptance of the teaching, contradictions be damned, perhaps such people were there. But we know from both conciliar and extraconciliar works by these thinkers that their heresy hunting was most often done in the form of Modus Tollens:

If Nestorius's view of Mary as Christ-bearer but not God-bearer is orthodox, then the person who is borne by Mary is not a divine person. But the person borne by Mary is a divine person. And so Nestorius's view is heretical.

Such careful searching for contradictions goes both ways in the debates, as the letters from Cyril and Nestorius included in the Council of Ephesus make clear. Nestorius did not argue in his replies that his view is contradictory, but that's okay. We can be confident, based on their writings, how the Fathers would have responded to such a move (i.e., not favorably).

Concerning political motivations, they were ample. Some important theologians of this era played the game well (e.g., Cyril of Alexandria), while others played it 
poorly (e.g., John Chrysostom ${ }^{19}$ ). That said, I know of no good evidence for thinking that doctrinally affirming that the divine nature is related to each distinct divine person by strict identity was a matter of political intrigue. And even if it were, that wouldn't give us any reason to think that the councils must be interpreted as requiring strict identity as the relation in question.

Thus, while all three of these features may well have been present among the bishops at the councils, there is little reason to think that the presence of these features lends any support to the thesis that, according to Conciliar Trinitarianism, the relation between the divine nature and the divine persons is one of strict identity. Such an answer to the Person-Nature question isn't found in the texts. I have provided three reasons in this section for thinking that such an answer is not only unincluded in the texts, but also inconsistent with the texts.

\subsection{Instantiation}

Consider, then, the second common interpretation of the relation between the divine nature and each divine person: instantiation. Instantiation is the relation that holds between something universal and a particular that has or exemplifies that universal. There's the Platonic form of courage (say), and then there's the war hero who is courageous. The relation that holds between the hero and that universal is called instantiation. On the view under consideration here, the relationship that holds between the divine nature and each divine person is instantiation; each of the three divine persons instantiates the divine nature.

There are some reasons for thinking that instantiation is the right way to understand the relation between the divine nature and the divine persons. For one thing, natures are typically viewed as abstract entities which one could have. Humanity, for instance, is often viewed as a thing in which you and I share. The term translated "divine nature" or "Godhead" (theotêtos) is an abstract noun, much like humanity. It stands to reason, some argue, that there is one universal of divinity instantiated by each of the three different divine persons.

Consider another reason that might militate in favor of the instantiation answer to the question of the relation between the divine persons and the divine nature. Were the nature an abstract nature, it would make sense why it couldn't be causally affected, changed, or diminished in an incarnation. Forms like Courage or Humanity can't be changed or affected, even if individual courageous humans can be. In that

\footnotetext{
${ }^{19}$ What do you think would happen to you if you were to liken Empress Eudoxia to both Jezebel and Herodias in your orations (Davis 1990, 137-38)?
} 
sense, the instantiation view of the nature fits well with the features predicated of the divine nature in the first seven councils.

On the other hand, there are at least two problems that this instantiation view has to face as an answer to the Person-Nature question, both having to do with the conciliar claim that there is only one God. First, consider a problem often raised against Social Trinitarianism, a type of instantiation view that builds into the unity of God much more than mere instantiation. The problem goes as follows. The instantiation view gives up monotheism. When we count human people, we count by individual instances of humanity. When my daughters, Mary, Beatrice, Edith, and Agnes, each instantiate the universal, Humanity, and each has proper characteristics such that we don't confuse them, what we have there are four humans, not a single human. ${ }^{20}$ So likewise, on the instantiation account, we ought to invert the line from the Athanasian creed, saying instead that there is not one God but three gods. ${ }^{21}$

Second, a problem with the conciliar and traditional focus on monotheism. Even aside from the claim that the instantiation view leads to polytheism, one can ask what the Christian emphasis on monotheism comes down to on this instantiation view. If this were the theory of the church Fathers, the view they adamantly asserted when saying that God is one, what were they meaning to say? They weren't meaning to say, on this view, that there's only one thing that instantiates the universal, Divinity. For, on this view, they meant that there are three things that instantiate that universal - the Father, the Son, and the Holy Spirit-in contrast to the quotation from Lateran IV above, which claims that there is one supreme thing that is the Father, Son, and Holy Spirit. So, what's the relevant one thing on this view? True, the Father is one thing, the Son one thing, the Spirit one thing, etc. But none of these three, on this instantiation view, is strictly identical with the thing that is the important one thing according to the ecumenical councils.

As we saw earlier from the councils, the relevant one thing is the nature, Godhead, or substance. And that thing, that nature, Godhead, or substance, is a universal on the instantiation view. So, the emphasis on monotheism turns out to be an emphasis on the number of universals of Divinity there are.

Why care strongly about the number of universals of Divinity there are? Consider a bloated ontology on which there are two universals for each kind term. To be human, for instance, one instantiates both Humanity1 and Humanity2. And so on

${ }^{20}$ This example is purely hypothetical insofar as it requires me to say that I do not confuse my four daughters.

${ }^{21}$ See the work of Beau Branson (2014) here, who defends the instantiation view of the divine nature. 
for other kinds. In such a case, there are two universals of divinity, Divinity1 and Divinity2, and anything divine instantiates both. Is that the view that they were trying to prohibit? Again, why would they care about that? The religion of the metaphysician might include grave warnings against multiplying entities beyond necessity. But Christian bishops wouldn't view this question of subtle metaphysics as a hill to die on.

Think about it another way. Christians wanted to safeguard the monotheism they inherited from Judaism (whether they succeeded is a separate question). Now, suppose a Jewish man were accused of polytheism. Here's a defense he could give on this instantiation view of the divine nature. He could say,

Yes, it is true; I worship the God of Israel, Baal of the Canaanites, Dagon of the Philistines, and countless others. But fear not! I only countenance a single universal, Divinity, which each of my many gods instantiates. As such, I'm still a monotheist.

I don't think Moses would be impressed. He'd probably throw some tablets. If we must speak in terms of instantiating a universal of Divinity, the Jewish emphasis on monotheism was not the claim that there is only one divinity universal. If we must speak in terms of instantiating a universal of divinity, the Jewish emphasis on monotheism was the claim that there is but one thing that instantiates that universal. That, though, is a claim not open to the person who interprets the conciliar texts in this instantiation manner. The instantiation view makes the emphasis on monotheism inexplicable. As such, I take the instantiation view to be inconsistent with the emphasis on monotheism found in Conciliar Trinitarianism.

\subsection{Other Answers?}

I conclude that more work needs to be done on what exactly the relation is between the divine persons and the divine nature. The relation cannot be one that requires either (i) transitivity and symmetry or (ii) obeys Leibniz's Law. Such a view collapses the three down to one, and thus is inconsistent with Conciliar Trinitarianism. Likewise, the relationship cannot be that of mere instantiation. Such a view runs afoul of monotheism and thus is inconsistent with Conciliar Trinitarianism. We need something in between, so to speak.

Historically, various conceptualizations of the relation in question have been offered. Some have argued that the relationship is one of virtual distinction. ${ }^{22}$ Others,

\footnotetext{
${ }^{22}$ See, for instance, Ott $(1960,68-75)$.
} 
following Scotus, have argued that it is not virtual distinction but formal distinction. ${ }^{23}$ More recently, the relation has been interpreted as numerical sameness without identity. ${ }^{24}$ One commonality among these views is that they all deny the conjunction of symmetry and transitivity of the relation in question. Ott $(1960,75)$ writes, following Aquinas (ST I q.28 a.3 ad.1):

The principle adduced against the dogma of the Trinity: two things which are equal to a third are equal among themselves, is valid only when the two things are in every respect, re et ratione, equal to a third thing. The Divine Persons and the Divine Essence are indeed really identical, but virtually (ratione) different. Thus the Three Persons are indeed identical in Essence, but different from one another in their relation to one another.

Ott here aims for a sort of real sameness that denies the conjunction of symmetry and transitivity. Spelling out that relationship, or more likely, family of potential relationships, and considering how it fares in the contemporary analytic discussion, would be a great project for someone.

A second project that one could take up is discerning what it could mean for the divine nature to be such that it "truly is the Father and the Son and the holy Spirit, the three persons together and each one of them separately" (Tanner 1990, 232). How can one thing truly be both a number of things together and each member of that number separately?25 Is this a key to unlocking the proper interpretation of the relation between the nature and the persons?

\section{Do the Divine Processions Imply Ontological Subordination in the Trinity?}

Consider now an example of the sort of internal contradiction worry that Conciliar Trinitarianism has to face. One general form of objection to any conjunction of propositions is to attempt to show that the truth of some subset of those propositions entails the falsity of some other member of that conjunction. If one can show that the conditional, if $\mathrm{P}$, then not $\mathrm{Q}$, is true, then one has shown that the conjunction, $P \& Q$, is false. In In Defense of Conciliar Christology, I called conditionals that take the truth of a part of Conciliar Christology as its antecedent and the falsity of another part as

\footnotetext{
${ }^{23}$ For a good discussion of Scotus on trinitarian theology and the formal distinction and abundant references to other discussions, see Spencer $(2017,128-29)$.

24 See the work of Brower and Rea (2005). For recent arguments against this view, see Leftow (2018).

${ }^{25}$ For discussion of this question, see Williams (2019).
} 
its consequent Unfriendly Conditionals (Pawl 2016d, 210-15). What are some unfriendly conditionals for Conciliar Trinitarianism?

One unfriendly conditional that is constructible from the discussion of the previous section is the following: If there are three divine persons, then it is false that there is one God. The Conciliar Trinitarian accepts the antecedent and denies the consequent of this conditional, and so denies its truth.

Another unfriendly conditional comes from consideration of the divine processions and the ontological perfection of each divine person. Does the pouring forth of the Son or Spirit asserted in the councils render the Son or Spirit somehow derivative in his attributes, lesser than the Father? Is the Spirit, on the conciliar teaching, powerful or wise through another, or through some sharing in another's power or wisdom? Conciliar Trinitarianism answers this question with a clear "No." Just a few lines after using the language of pouring forth, quoted in Section II, Cyril writes:

we do not say that the Spirit is wise and powerful through some sharing with another, for he is all perfect and in need of no good thing. Since he is the Spirit of the power and wisdom of the Father, that is the Son, he is himself, evidently, wisdom and power. (Tanner 1990, 57-58)

Likewise, Chalcedon teaches, the Son is no lower than the Father, though he is born of the Father:

$[\mathrm{H}] \mathrm{e}$ was born God from God, almighty from the Almighty, co-eternal from the Eternal, not later in time, not lower in power, not unlike in glory, not distinct in being. (Tanner 1990, 77)

We see, then, that, according to Conciliar Trinitarianism, the processions of the Second and Third Persons do not imply an ontological inferiority of those persons to the Father.

Some have argued that one part of Conciliar Trinitarianism - the processions implies the falsity of another part of Conciliar Trinitarianism - the ontological parity of the divine persons. As such, some have argued for a conditional unfriendly to Conciliar Trinitarianism. Call that claim-that the processions imply a denial of ontological parity - The Procession Conditional, or just The Conditional for short.

If The Conditional were true, then Conciliar Trinitarianism would be false. For Conciliar Trinitarianism says that there are personal processions in the Trinity (PP) and there is ontological parity (OP) among the persons of the Trinity. And the 
Conditional says that if PP is true, then OP is false. Those three claims are inconsistent: any two of them imply the falsehood of the third. So, if The Conditional were true, then at least one of the remaining claims is false. But, if one of the remaining claims is false, then any conjunction that includes that claim is false. Conciliar Trinitarianism is one such conjunction. So, if The Conditional is true, then (by hypothetical syllogism) Conciliar Trinitarianism is false. What the proponent of Conciliar Trinitarianism must do, then, is deny the truth of The Conditional. To do so, the proponent of Conciliar Trinitarianism should investigate the arguments of the proponents of The Conditional. What are those arguments?

We find one in a recent publication by William Lane Craig. Craig writes:

This doctrine of the generation of the Logos from the Father cannot, despite assurances to the contrary, but diminish the status of the Son because He becomes an effect contingent upon the Father. Even if this eternal procession takes place necessarily and apart from the Father's will, the Son is less than the Father because the Father alone exists $a$ se, whereas the Son exists through another (ab alio). (Craig 2019, 27)

The reasoning for The Conditional can be presented as follows. If, as Conciliar Trinitarianism says, the Son proceeds from the Father, then the Father but not the Son is $a$ se. If the Father but not the Son is $a$ se, then there is not ontological parity between the Father and the Son. Thus, (by Hypothetical Syllogism) if the Son proceeds from the Father, then there is not ontological parity between the Father and the Son. Similar argumentation can show that there is a lack of ontological parity between the Father and the Holy Spirit. Thus, The Conditional is true.

Ryan Mullins offers another recent argument for the truth of The Conditional, along similar lines. Mullins (2017, 195-98) claims that anything that is God is $a$ se and self-sufficient. As he defines the terms,

A being exists $a$ se if and only if its existence is not dependent upon, nor derived from, anything outside of itself ...

A being is self-sufficient if and only if its essential nature is in no way dependent upon, nor derived from, anything outside of itself. (Mullins 2017, 196)

Were the Son and Spirit to proceed from the Father, as Conciliar Trinitarianism requires, then they would both lack aseity and self-sufficiency. So, neither would be divine. Since not divine, they would not have ontological parity with the Father, who is divine. Thus, if the Son and Spirit proceed, they lack ontological parity. In other words, The Conditional is true. 
How ought a Conciliar Trinitarian respond to Craig's and Mullin's arguments? Craig suggests that Christians ought to understand the processional language as processions in the economic trinity, not as internal to the divine life. The Word is begotten from the Father in time as a man, but this begetting does not carry over into the internal relations within the Trinity. As Craig writes,

it may well be arbitrary which person plays the role of "Father" and which of "Son." These titles have reference to the economic Trinity, to the roles played by the three persons in the plan of salvation with respect to the created order. The Son is whichever person becomes incarnate, the Spirit is he who stands in the place of and continues the ministry of the Son, and the Father is the one who sends the Son and Spirit. (Craig 2019, 30)

Understood in this way, we can still make sense of the processional language of scripture without committing ourselves to processions internal to the divine life. As such, for Craig, we could avoid his worries about the Son and Spirit being inferior to the Father.

Such a response is not open to the Conciliar Trinitarian. As Craig $(2019,29)$ notes, "Nicene Orthodoxy" requires processions internal to the Trinity, and not merely a begetting in time. For the Son is claimed in the Nicene-Constantinopolitan Creed to be "begotten from the Father before all the ages" (Tanner 1990, 5). And even if there were a way to understand this claim such that it didn't imply an internal procession of Son from Father, other conciliar texts preclude such a reading. See, for instance, the $2^{\text {nd }}$ Anathema of $2^{\text {nd }}$ Constantinople, which says:

If anyone will not confess that the Word of God has two nativities, that which is before all ages from the Father, outside time and without a body, and secondly that nativity of these latter days when the Word of God came down from the heavens and was made flesh of holy and glorious Mary, mother of God and ever-virgin, and was born from her: let him be anathema. (Tanner 1990, 114)

Here the word translated "nativities" (gennēseis; nativitates) is the same word we find in the earlier creeds for begetting. The councils teach that the Son has two begettings, one from the Father outside of time (achronōs; sine tempore), the other in time from the holy and glorious ever-virgin Mary. As such, the Conciliar Trinitarian is not free to jettison the eternal generation of the Son.

What ought the Conciliar Trinitarian do? Here I will develop one response modeled on my work on Conciliar Christology. The councils predicate apparently incompatible predicates of the one God-man, Jesus Christ. He is, for instance, both 
passible and impassible. ${ }^{26}$ We find such claims in the fathers and Medievals, too. For just a small sampling, Athanasius, John of Damascus, and Thomas Aquinas all predicate both passibility and impassibility to Jesus Christ. ${ }^{27}$ How can we understand these attributes such that this isn't a blatant contradiction?

I have argued for a solution to this problem that revises our understandings of the truth conditions for these allegedly contradictory pairs of predicates. ${ }^{28} \mathrm{I}$ think the best response for the Conciliar Christologist is to defend truth conditions for the predicates that have the following form: the predicate, "passible," is apt of a thing if and only if it has a concrete nature that is able to be causally affected. Likewise, the predicate, "impassible," is apt of a thing if and only if it has a concrete nature that is unable to be causally affected. ${ }^{29}$ Since Christ has a divine nature that, as we've seen, is unable to be causally affected, given the teaching of the ecumenical councils, he fulfills the conditions for being impassible. Since he has a human nature that can be causally affected-can be hung on a cross-he fulfills the conditions for being passible. He is both at the same time without a contradiction. I have argued that we can understand "immutable" and "mutable," "atemporal" and "temporal," and "simple" and "complex" in the same revised manner. ${ }^{30}$ Such an understanding of the truth conditions for these predicates is not a novelty; we find it at least as far back as the work of Gabriel Biel (died 1495). ${ }^{31}$

So likewise, we can understand aseity. Here we won't be able to appeal to multiple natures, as the Holy Spirit only has the one divine nature. But we can maintain the has a nature that method of providing truth conditions for the divine predicates. Such a method yields beneficial results for the Conciliar Trinitarian here, just as it does in Conciliar Christology.

Rather than something being a se when, as Mullins puts it, "its existence is not dependent upon, nor derived from, anything outside of itself," something is a se when it has a nature the existence of which is not dependent upon, nor derived from,

${ }^{26}$ See Tanner 1990, 162. For discussions of examples, see Pawl (2014; 2015; 2016d; 2016b; 2018; 2019b; 2020a; Forthcoming).

${ }^{27}$ For Athanasius, see Anatolios (2004, 70); for Damascus, see De Fide Orth. iii, 4; for Aquinas, see ST III q.16 a.12 ad.2.

28 See Pawl (2014; 2016d, chap. 7).

${ }^{29}$ This is not to say that all predicates have the same form. They do not. Predication is a gruesome affair, and one can always coin new predicates with stipulated truth conditions to frustrate any helpful, illuminating theory of how predicates must function. For more on this, see Pawl (2016d, 13536; 2020b, sec. 3).

${ }^{30}$ See Pawl (2016d, chap. 8; 2018; Forthcoming).

${ }^{31}$ See Pawl (2019a, 442-44). I thank Richard Cross for referring me to the Biel text. 
anything outside of itself. Then, since each divine person has a nature that is not dependent or derived, each divine person is $a$ se.

We can see how this revised understanding of the conditions for aseity allows the Conciliar Trinitarian to deny a premise of both Craig's and Mullins's arguments. As I presented it, Craig required the premise "if, as Conciliar Trinitarianism says, the Son proceeds from the Father, then the Father but not the Son is a se." This, though, turns out to be false. For the Son is a se on the revised truth conditions. Thus, the Conciliar Trinitarian will say that the antecedent of that conditional premise is true, but the second conjunct of the consequent (i.e., the claim that the Son is not $a$ se) is false on the right understanding of aseity, so the whole conditional is false.

Likewise, Mullin's premise (as I represent the argument) "were the Son and Spirit to proceed from the Father, as Conciliar Trinitarianism requires, then they would both lack aseity and self-sufficiency" would be false. For each divine person has a nature that fulfills the conditions needful for that person to be properly called "a se." And each has an essential nature - the one divine nature - that is not dependent on or derived from anything outside that nature. So, each is self-sufficient, too.

We see, then, that the Conciliar Trinitarian has at least one method open for answering these challenges. This method does not require inventing a new method of understanding divine predicates out of whole cloth. We find it at least 500 years ago in Christological writings.

Suppose the objection is put a bit differently. ${ }^{32}$ The Spirit depends on another because the Father spirates the Spirit. But the Spirit is independent because the Spirit is God and anything that is God is independent. So, it seems the Spirit is both dependent and independent, which is contradictory. Thus, the conjunction of procession and divinity seems impossible after all. The Conditional is vindicated!

Notice that my preferred strategy of adding a has a concrete nature clause to the ontological conditions under which the relevant predicates-independent and dependent-are satisfied will not work here. Such a response requires saying that to be independent is to have a concrete nature that fulfills certain conditions and to be dependent is to have a nature that does not fulfill those conditions. As I noted a few paragraphs above, the Spirit, unlike the Son, only has one nature; thus, the Spirit can't be both independent and dependent in that manner. What to do?

First, note that the Conditional is vindicated here only if "independent" and "dependent" are defined in contradictory ways, such that we must predicate one thing of the Spirit in virtue of being spirated and deny that very same thing of him in virtue of being divine. How are the terms defined? It is of no help here to say that

\footnotetext{
${ }^{32}$ I owe this objection, and much of its wording, to Joseph Jedwab.
} 
being dependent means being dependent, darn it, and being independent means being independent, and those are contradictory! For we already have a recipe for understanding the definitions of the terms such that they are not contradictoryadding the has a concrete nature clause. On such a definition, the Spirit is independent and is not dependent, since the Spirit (1) has a nature that is independent of all else and (2) has no nature that is dependent on another thing. Similarly, in my previous responses to the arguments of Mullins and Craig I've proposed that the Spirit is a se and not not a se. I said that because of how I defined the term aseity; the Spirit has a nature that depends on nothing for its existence, but has no nature that depends on something for its existence.

But suppose that the objector refuses to countenance my definition.

You know what dependence means, you scoundrel! And even if you don't have a good, single understanding of it-Fine. Take every way you've ever thought that something depends on something else-nothing that is God can depend in any of those ways, no matter what, period. That's independence. That's what intuitions supported by perfect being theology require. But procession is a form, some form, of dependence. So, again, leaving your chicanery with predicates to one side, we see the vindication of The Conditional..$^{33}$

In response, let the objector have the term. Understand independence as she suggests. I still think that there is a good response, based on how the Christian must understand other predicates put forward by perfect being theology. Consider, for instance, immutability. Perfect being theologians might feel inclined to suggest that we take every way you've ever thought about something changing - nothing that is God can change in any of those ways, no matter what, period. That's immutability. ${ }^{34}$ Or likewise, nothing that is God can be composite in any of those ways, no matter what, period, or be causally affected in any of those ways, or be effable in any of those ways, ${ }^{35}$ no matter what, period. The truth is, Christian doctrine is inconsistent with all of those claims. Something that is God can change, can suffer, can be composed of body and soul, flesh and blood, can be understood, at least understood as being a man, etc. The doctrine of the Incarnation requires as much. None of these "no matter what, period" versions of the divine attributes have ever been consistent with Christianity. It is no surprise that other overly strong versions of the divine attributes-aseity, no matter what, period; independence, no matter what, period-

\footnotetext{
${ }^{33}$ The wording of this speech is not due to Joseph; he's too nice to call me a scoundrel.

${ }^{34}$ Elsewhere (Pawl 2018, 920) I called this "super-duper immutability."

${ }^{35}$ Elsewhere (Pawl 2020b) I called this "the ridiculously strong doctrine of divine ineffability."
} 
face a similar fate. So if we let the objector have the term "independent" as understood in this strong, no matter what, period, sense of the term, then I accept that the Spirit is dependent and not independent in that particular sense. I also deny that anything that is God must be independent in that sense, just as I deny, for incarnational reasons, that anything that is God must be immutable no matter what, period, or impassible no matter what, period, or...

As a final foray down this dialectic, what if the objector retorts that drawing on the incarnation is not relevant here. For all the examples I could give of "no matter what, period" immutability or impassibility or simplicity or ineffability or independence being violated are incarnational examples. And the Spirit is not incarnate! Yes, qua human, the Son can change. But qua divine, the Son is, for the perfect being theologian, immutable, impassible, simple, ineffable, and independent in the "no matter what, period" sense of the terms. The Spirit, then, must be likewise. What now?

Here I fear we've come full circle to my initial has a nature that understandings of the predicates, and it is the opponent who has led us here. When the objector says that the Son or Spirit is, qua divine, immutable or impassible or simple or ineffable or independent, what does that amount to? What does the "qua" locution do for the claim? On the view I think is best, the "qua" functions as an ontological laser pointer, pointing to the ontological principle in virtue of which the predication is true. Here, the Spirit is independent because of the divine nature, that is, because the concrete nature is a certain way - namely, the way I provided in my account of aseity above. And, on my same preferred account, as I said above, the Spirit is not "dependent" in a sense that is contradictory to this independence.

If the opponent denies my preferred account of the "qua," she still needs an account of "qua." Heaven help her if, after all this digression, the because of in the "qua" includes any dependence at all. For instance, if the Spirit is worshipful because the Spirit is divine (that is, has the divine nature). For that's some sort of dependence. Whence the independence, no matter what, period, if the Spirit's worshipfulness depends upon his divinity?

Moreover, it is a common, traditional view that each divine person could have become incarnate, even though only the Son in fact did. ${ }^{36}$ But then, it is possible that the Father or Spirit be causally affected. For it is possible that they become incarnate, and, necessarily, if incarnate, then causally affected. The same is true for other attributes. The upshot, then, is that if the other persons could become incarnate, the

\footnotetext{
${ }^{36}$ For discussion of multiple incarnations and references to other literature on the topic, see Pawl (2016a; 2016c; 2019b, chaps. 2 \& 3).
} 
"no matter what, period" attributes I've been discussing are not satisfied by any of the divine persons. The Spirit could be dependent as an unborn child is on her mother. So the Spirit's divinity does not require that the Spirit must not be dependent in every sense of "dependent." Being independent, no matter what, period, is not an attribute that divinity requires.

To summarize: Do the divine processions imply the ontological inferiority of the Son and Spirit, as the Procession Conditional claims? Craig and Mullins argue for the truth of the Procession Conditional by means of aseity and independence. Only the Father is $a$ se or independent, and so the Son and Spirit, given the doctrine of divine procession, are inferior to the Father. What to make of this reasoning? It all depends upon what we mean by "aseity" and "independence."

When understood in my preferred senses of the terms, "aseity" and "independence" require only that the thing have a nature that doesn't depend on something else. The Holy Spirit has aseity and independence in that sense. Since the Holy Spirit only has one nature, the divine nature, the Holy Spirit lacks dependence, where "dependence" is understood to be the contradictory of "independence." Lacking this sort of dependence is not inconsistent with depending on the Father in other senses of the term.

Suppose the opponent denies this last claim, asserting that aseity, when properly understood, requires that the thing that is a se not depend on anything else in any sense of the term "depend." If the opponent refuses to countenance the conditions for the satisfaction of these predicates that I offer, but instead relies on a(n overly) strong notion of the divine attributes, which I've here called "no matter what, period" attributes, then the Christian should say that those attributes are not required for divinity. One piece of evidence that they are not required for being divine comes from reflection on the incarnation.

In either case, then, whether we understand "aseity" in my sense, or in the "no matter what, period" sense, the antecedent of the conditional does not imply its consequent. In my sense of the term, it is true that the Spirit is a se, but that doesn't imply inferiority. In the opponent's sense, it is false that any of the divine persons are $a s e$, and so their having aseity could not imply their inferiority. In either case, then, The Conditional is false.

\section{Conclusion}

In this article, I have presented the teachings of Conciliar Trinitarianism - the trinitarian teachings of the first seven ecumenical councils. I then discussed two questions that arise in light of those teachings. First, a question I called the Person- 
Nature question: How are the divine persons related to the divine nature? Second, a question about the internal consistency of Conciliar Trinitarianism: Does divine procession imply ontological subordination among the divine persons? To the first, I argued that Conciliar Trinitarianism precludes certain answers, but doesn't, itself, require a specific answer. To the second, I provided one means the Conciliar Trinitarian might use to deny the unfriendly conditional that procession implies ontological subordination. ${ }^{37}$

\section{Bibliography}

Anatolios, Khaled. 2004. Athanasius. New York: Routledge. https://doi.org/10.4324/9780203457634.

Baber, H. E. 2002. "Sabellianism Reconsidered." Sophia 41 (2): 1-18. https://doi.org/10.1007/BF02912232.

Baber, H. 2008. “Trinity, Filioque and Semantic Ascent.” Sophia 47 (2): 149-160. https://doi.org/10.1007/s11841-008-0061-8.

Baber, H. 2015. "The Trinity." Faith and Philosophy 32 (2): 161-171. https://doi.org/10.5840/faithphil201541336.

Baber, H. 2016. “Trinity, Generality, and Dominance." Religious Studies 52 (4): 435449. https://doi.org/10.1017/S003441251500058X.

Baber, H. 2019. The Trinity: A Philosophical Investigation. Scm Press.

Bohn, Einar Duenger. 2011. "The Logic of the Trinity." Sophia 50 (3): 363-374. https://doi.org/10.1007/s11841-011-0265-1.

Branson, Beau. 2014. "The Logical Problem of the Trinity." PhD Thesis, University of Notre Dame.

Brower, Jeffrey E., and Michael C. Rea. 2005. "Material Constitution and the Trinity." Faith and Philosophy 22 (1): 57-76. https://doi.org/10.5840/faithphil200522134.

Cain, James. 2016. "On the Geachian Theory of the Trinity And Incarnation." Faith and Philosophy 33 (4): 474-486. https://doi.org/10.5840/faithphil201610565.

Craig, William Lane. 2019. "Is God the Son Begotten in His Divine Nature?" TheoLogica: An International Journal for Philosophy of Religion and Philosophical Theology 3 (1): 22-32. https://doi.org/10.14428/thl.v2i3.16583.

\footnotetext{
${ }^{37}$ I thank the Logos Institute for a Senior Research Fellowship (2019), during which this article was written, and Templeton Religious Trust (ID: TRT0095/58801) for funding that fellowship. I thank Beau Branson, Dennis Bray, Mark DelCogliano, Matthew Joss, Dale Tuggy, Scott Williams, and two anonymous referees for comments on the manuscript or helpful discussion. I thank the John Templeton Foundation for a grant (ID: 61012), which provided some of the research time I used in the writing of this article.
} 
Davidson, Matthew. 2016. "The Logical Space of Social Trinitarianism." Faith and Philosophy 33 (3): 333-357. https://doi.org/10.5840/faithphil201661663.

Davis, Leo D. 1990. The First Seven Ecumenical Councils (325-787): Their History and Theology. Collegeville, Minn.: Liturgical Press.

Dupuis, Jacques. 2001. The Christian Faith: In the Doctrinal Documents of the Catholic Church. Edited by Jacques Dupuis. 7th Rev. Staten Island, NY: Alba House.

Fisher, Matthew Zaro. 2016. "A Supervenient Trinity: An Alternative to Latin and Social Trinitarian Theories." The Heythrop Journal 57 (6): 964-73. https://doi.org/10.1111/heyj.12138.

Grant, W. Matthews, and Mark K. Spencer. 2015. "Activity, Identity, and God." Studia Neoaristotelica 12 (2): 5-61. https://doi.org/10.5840/studneoar20151225.

Hasker, William. 2009. “A Leftovian Trinity?" Faith and Philosophy 26 (2): 154-166. https://doi.org/10.5840/faithphil200926224.

Hasker, William. 2013. Metaphysics and the Tri-Personal God. Oxford: Oxford University Press. https://doi.org/10.1093/acprof:oso/9780199681518.001.0001.

Hasker, William. 2016. "Is Divine Simplicity a Mistake?" American Catholic Philosophical Quarterly 90 (4): 699-725. https://doi.org/10.5840/acpq201691295.

Hasker, William. 2017a. "A Compositional Incarnation." Religious Studies 53 (4): 433447. https://doi.org/10.1017/S0034412516000378.

Hasker, William. 2017b. “'God's Only Begotten Son': A Reply to R. T. Mullins." European Journal for Philosophy of Religion 9 (4): 217-237. https://doi.org/10.24204/ejpr.v9i4.1942.

Hasker, William. 2018. "Can a Latin Trinity Be Social? A Response to Scott M. Williams." Faith and Philosophy 35 (3): 356-366. https://doi.org/10.5840/faithphil2018613104.

Hasker, William. 2019. “The One Divine Nature.” TheoLogica: An International Journal for Philosophy of Religion and Philosophical Theology 3 (2). https://doi.org/10.14428/thl.v3i1.2893.

Jedwab, Joseph. 2015. "Against the Geachian Theory of the Trinity and Incarnation." Faith and Philosophy 32 (2): 125-145. https://doi.org/10.5840/faithphil201541335.

Jedwab, Joseph, and John A. Keller. 2019. "Paraphrase and the Doctrine of the Trinity." Faith and Philosophy. https://doi.org/10.5840/faithphil201951122.

Leftow, Brian. 1999. "Anti Social Trinitarianism." In Trinity, The, 203-249. Oxford University Press. https://doi.org/10.1093/0199246122.003.0009.

Leftow, Brian. 2009. "Aquinas, Divine Simplicity and Divine Freedom." In Metaphysics and God: Essays in Honor of Eleonore Stump, edited by Kevin Timpe. Routledge. 
Leftow, Brian. 2010. “Two Trinities: Reply to Hasker: Brian Leftow.” Religious Studies 46 (4): 441-447. https://doi.org/10.1017/S003441251000017X.

Leftow, Brian. 2012. "On Hasker on Leftow on Hasker on Leftow." Faith and Philosophy 29 (3): 334-339. https://doi.org/10.5840/faithphil201229333.

Leftow, Brian. 2018. “The Trinity Is Unconstitutional.” Religious Studies 54 (3): 359376. https://doi.org/10.1017/S0034412518000215.

Long, Joseph. 2019. "Mystery of the Trinity: A Reply to Einar Bøhn." Sophia 58 (2): 301-307. https://doi.org/10.1007/s11841-019-0710-0.

McCall, Thomas H. 2014. "Trinity Doctrine: Plain and Simple." In Advancing Trinitarian Theology, edited by Oliver D. Crisp and Fred Sanders, 42-59. Grand Rapids, Michigan: Zondervan.

Molto, Daniel. 2017. "The Logical Problem of the Trinity and the Strong Theory of Relative Identity." Sophia 56 (2): 227-245. https://doi.org/10.1007/s11841-017_ 0612-y.

Mooney, Justin. 2018. "A New Logical Problem for the Doctrine of the Trinity." Religious Studies 54 (1): 1-13. https://doi.org/10.1017/S0034412516000342.

Mullins, R. T. 2017. "Hasker on the Divine Processions of the Trinitarian Persons." European Journal for Philosophy of Religion 9 (4): 181-216. https://doi.org/10.24204/ejpr.v9i3.1941.

Ott, Ludwig. 1960. Fundamentals of Catholic Dogma. 4th ed. St. Louis, MO: Herder.

Owen, Matthew, and John Anthony Dunne. 2019. "The Son of God and Trinitarian Identity Statements." TheoLogica: An International Journal for Philosophy of Religion and Philosophical Theology 3 (1): 33-59. https://doi.org/10.14428/thl.v2i3.18413.

Page, Ben. 2017. “The 'Power'-Ful Trinity." European Journal for Philosophy of Religion 9 (4): 155-180. https://doi.org/10.24204/ejpr.v9i4.1875.

Paoletti, Michele Paolini. 2019. "The Holy Trinity and the Ontology of Relations." Sophia, 1-19. https://doi.org/10.1007/s11841-019-0719-4.

Pawl, Timothy. Forthcoming. "Simplicity Incarnate." Manuscript.

Pawl, Timothy. 2014. "A Solution to the Fundamental Philosophical Problem of Christology." The Journal of Analytic Theology 2: 61-85.

Pawl, Timothy. 2015. "Conciliar Christology and the Problem of Incompatible Predications." Scientia et Fides $3 \quad$ (2): 85-106. https://doi.org/10.12775/SetF.2015.019.

Pawl, Timothy. 2016a. “Brian Hebblethwaite's Arguments against Multiple Incarnations." Religious $\quad$ Studies $52 \quad$ (01): 117-130. https://doi.org/10.1017/S0034412514000626.

Pawl, Timothy. 2016b. “Temporary Intrinsics and Christological Predication." In Oxford Studies in Philosophy of Religion, Volume 7, edited by Jonathan L Kvanvig, 
157-89. Oxford: Oxford University Press, USA. https://doi.org/10.1093/acprof:0so/9780198757702.003.0007.

Pawl, Timothy. 2016c. "Thomistic Multiple Incarnations." The Heythrop Journal 57 (2): 359-70. https://doi.org/10.1111/heyj.12230.

Pawl, Timothy. 2016d. In Defense of Conciliar Christology: A Philosophical Essay. 1 edition. Oxford; New York: OUP Oxford. https://doi.org/10.1093/acprof:oso/9780198765929.003.0001.

Pawl, Timothy. 2018. "Conciliar Christology and the Consistency of Divine Immutability with a Mutable, Incarnate God." Nova et Vetera 16 (3): 913-37. https://doi.org/10.1353/nov.2018.0066.

Pawl, Timothy. 2019a. "Explosive Theology: A Reply to Jc Beall's 'Christ-A Contradiction'." Journal of Analytic Theology 7: 440-51. https://doi.org/10.12978/jat.2019-7.190824150011.

Pawl, Timothy. 2019b. In Defense of Extended Conciliar Christology: A Philosophical Essay. Oxford; New York, NY: Oxford University Press. https://doi.org/10.1093/oso/9780198834144.001.0001.

Pawl, Timothy. 2020a. The Incarnation. Cambridge Elements. Cambridge; New York: Cambridge University Press.

Pawl, Timothy. 2020b. "The Metaphysics of the Incarnation: Christ's Human Nature." In Herausforderungen Und Modifikationen Des Klassischen Theismus, edited by Thomas Marschler and Thomas Schärtl, forthcoming. Munster: Aschendorff.

Pickup, Martin. 2016. "The Trinity and Extended Simples." Faith and Philosophy 33 (4): 414-440. https://doi.org/10.5840/faithphil2016101170.

Spencer, Mark K. 2017. "The Flexibility of Divine Simplicity." International Philosophical Quarterly 57 (2): 123-139. https://doi.org/10.5840/ipq201731682.

Swinburne, Richard. 2018. "The Social Theory of the Trinity." Religious Studies 54 (3): 419-437. https://doi.org/10.1017/s0034412518000203.

Tanner, Norman P. 1990. Decrees of the Ecumenical Councils 2 Volume Set. Washington, D.C.: Georgetown University Press.

Thom, Paul. 2012. The Logic of the Trinity: Augustine to Ockham. New York: Fordham University Press. https://doi.org/10.5422/fordham/9780823234769.001.0001.

Tuggy, Dale. 2013. Trinity. www.lulu.com.

White, Thomas Joseph. 2016a. "Nicene Orthodoxy and Trinitarian Simplicity." American Catholic Philosophical Quarterly 90 (4): 727-750. https://doi.org/10.5840/acpq201691397.

White, Thomas Joseph. 2016b. "Divine Simplicity and the Holy Trinity." International Journal of Systematic Theology 18 (1): 66-93. https://doi.org/10.1111/ijst.12133. 
Williams, Scott M. 2013. "Indexicals and the Trinity: Two Non-Social Models." Journal of Analytic Theology 1 (1): 74-94.

Williams, Scott M. 2017. "Unity of Action in a Latin Social Model of the Trinity." Faith and Philosophy 34 (3): 321-346. https://doi.org/10.5840/faithphil20178385.

Williams, Scott M. 2019. "Persons in Patristic and Medieval Christian Theology." In Persons: A History, edited by Antonia LoLordo, 52-86. Oxford: Oxford University Press. https://doi.org/10.1093/oso/9780190634384.003.0004.

Published Online: January 25, 2020 